\title{
Serebral Palsili Çocuklarda Adaptif Cihaz Kullanımını Etkileyen Faktörler
}

\author{
Factors Affecting The Use of Adaptive Devices in Childeren With Cerebral Palsy
}

\section{Mehmet Kurtaran}

${ }^{1}$ Trakya Üniversitesi Sağlık Hizmetleri Meslek Yüksekokulu Ortopedik Protez ve Ortez Programı

Yazı̧ma Adresi / Correspondence:
Mehmet Kurtaran
Trakya Üniversitesi Sağlık Hizmetleri Meslek Yüksekokulu Ortopedik Protez ve Ortez Programı
T: + $905423181586 \quad$ E-mail : fzt.mehmetkurtaran@hotmail.com
Geliş Tarihi / Received : 23.06.2020 Kabul Tarihi / Accepted : 29.09.2020
Orcid :
Mehmet Kurtaran https://orcid.org/0000-0001-8257-4400
( Sakarya Tip Dergisi / Sakarya Med J 2020, 10(4):592-599) DoI: 10.31832/smj.756912

\footnotetext{
$\ddot{0} z$

Amaç Serebral Palsili (SP) çocuklarda adaptif cihazların (AC) kullanım düzeyi tespit etmek ve AC’lerin kullanımı ile ilişkili faktörlerin aileler ve fizyoterapistler tarafindan değerlendirilmesi amaçland.

Gereç ve Çalșmaya 0-18 yaș arası 93 SP’li çocuk ile aileleri ve 50 fizyoterapist dahil edildi. Çocukların fonksiyonel seviyeleri Kaba Motor Fonksiyon Sınıflama Sistemi (KMFSS) ile

Yöntem değerlendirildi. AC’lerin kullanımı ile ilișkili faktörler araștırmacı tarafından beșli likert skalası kullanılarak olușturulan bir formun aileler ve fizyoterapistlerin cevaplaması ile değerlendirildi.

Bulgular SP'li çocukların \%30,10’u AC kullanmaktaydı. Fizyoterapistler tarafından önerilen AC kullanım gerekliliği \%67,70 idi. AC kullanımı ile KMFSS seviyeleri arasında istatistiksel anlamlı ilişki bulundu ( $\mathrm{p}=0,003)$. AC kullanan SP'li çocukların ailelerinin \% \% 75 'inin cihazlara erişimde çeşitlli zorluklar ile karşıllaştıkları, \%82,10'u çocuklarının bu cihazları kullanmalarından memnun olduklarını görüldü. Fizyoterapistlerin \%98'inin SP rehabilitasyonunda AC kullanımı önemli gördüğ̈̈, \%94’ünün kullanılmasından memnun olduğu bulundu.

Sonuç SP’li çocuklarda AC kullanımı ile fonksiyonel seviyeleri arasında anlamlı ilişki olmakla birlikte, AC kullananların sayısı önerilenin çok altında yer almaktadır. Ailelerinin cihazlara erişiminde ekonomik zorluk yaşamasına rağmen hem ailelerin hem de fizyoterapistlerin SP rehabilitasyonunda AC’lerin kullanılmasından memnun oldukları görüldü.

Anahtar Adaptif cihaz; Fonksiyonel seviye; Memnuniyet; Serebral palsi

Kelimeler

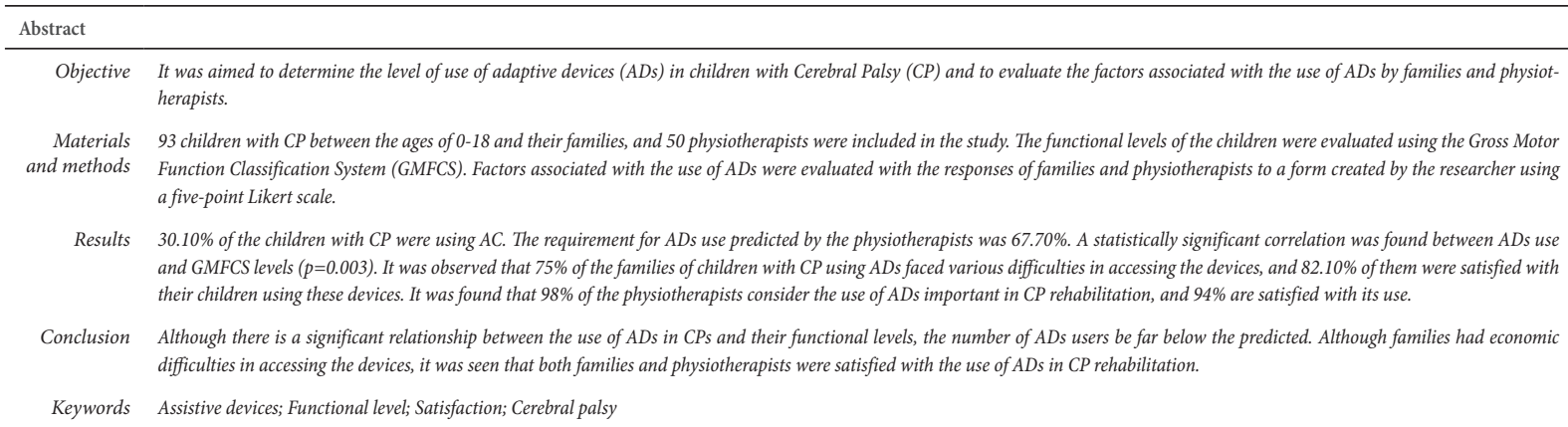




\section{GIIRIŞ}

Serebral Palsi (SP), çocuklarda kronik engelliliğin en yaygın nedenlerinden biridir ve sıklığ 1000 canlı doğumda 2 ile 3 arasında görülmektedir. ${ }^{1,2}$ Gelişmekte olan fetüste veya yeni doğanda görülen beyin hasarına bağlı olarak hareket ve postürü etkileyen ilerleyici olmayan bir grup bozukluk olarak tanımlanmaktadır. ${ }^{3}$

SP tedavisinde en önemli rolü rehabilitasyon uygulamaları oluşturmaktadır. Rehabilitasyonun amacı çocukta var olan potansiyeli açığa çıkararak geliştirmesine yardımcı olmak ve çocuğun maksimum düzeyde bağımsızlık kazanmasını sağlamak olarak özetlenebilir., ${ }^{4,5}$ Adaptif cihazlar (AC) SP rehabilitasyonunda gerekli ve yararlı bir yardımcı olarak görülmektedir. Bu cihazlar SP'li çocuklara destek sağlamakta, fonksiyonel yetenek ve mobiliteye yardım etmektedir. ${ }^{6}$ Literatürde SP’li çocukların mobilitesini değerlendiren bazı çalışmalarda AC’lerin mobiliteye yardımcı amaçla kullanıldığ 1 belirtilmektedir. ${ }^{7,8}$ Baston, koltuk değneği ve yürüteç gibi AC’ler denge ve güvenliği sağlamak, fonksiyonları düzeltmek, yük dağılımını düzenlemek ve dayanıklılığı artırmak amacıyla kullanılmaktadır. ${ }^{9}$ Bunların dışında oturma destekleri, pozisyonlama gereçleri ve ayakta dik konumlandırma cihazları ve bunların varyasyonları bulunmaktadır. Her bir AC konforlu, güvenli, kullanımı kolay ve ilgi çekici olmalıdır. Çocuk aktif kontrolünü kazandıkça destek sistemlerini azaltmak amacıyla sıklıkla yeniden değerlendirilmelidir. ${ }^{10}$

SP'nin sonuçlarına bağlı olarak fonksiyonel mobilite gibi aktiviteler kısıtlanmaktadır. ${ }^{11}$ Motor becerilerin ve aktivite limitasyonunun sınıflandırılması SP'li bir çocuk için önemlidir çünkü tedavide yol göstermekte ayrıca motor beceriler sınırlandıkça daha çok desteğe, yardımcı araç gerece ihtiyaçları olmaktadır. ${ }^{12,13}$ Buna karşın SP’li çocukların motor becerilerini arttırmak amacıyla ihtiyaç duydukları AC'lere yeterince sahip olmadıkları belirtilmektedir. $\mathrm{Bu}$ duruma neden olarak ailelerin maddi imkanlarının kısıtlı olması, AC’ler hakkında yeterli bilgiye sahip olmamaları ve çocuklarına karşı aşırı koruyucu davranmaları gösterilmektedir. ${ }^{14}$ Ayrıca araştırmacılar ve klinisyenler için piyasada bulunan AC’lerin etkisi hakkında yeterli bilgi bulunmamaktadır. ${ }^{15}$ Cihazlarla ilgili maliyet, çeşitlilik, etkinlik, memnuniyet konusundaki belirsizlikler SP’li çocuklara AC önerisinde bulunmak için güçlü kanıtlar sunmamaktadır. ${ }^{16}$ Literatürde SP'li çocuklarda AC kullanım düzeyini, ailelerin ve bu alanda çalışan fizyoterapistlerin bu cihazlara ilişkin memnuniyetlerine yönelik yeterli çalışma bulunmamaktadır. Bu nedenle yeni araştırmalara ihtiyaç duyulmaktadır. Bu çalışmanın amacı SP'li çocuklarda AC’lerin kullanım düzeyini belirlemek, aileler ve fizyoterapistler tarafından belirtilen AC’lerin kullanımı ile ilişkili faktörleri tespit etmektir.

\section{GEREÇ ve YÖNTEMLER}

Çalışma tanımlayıcı araştırma olarak İstanbul ilinde beş farklı rehabilitasyon merkezinden 0-18 yaş arası 93 (46 kız, 47 erkek) SP'li çocuk ile çocukların fizyoterapi uygulamalarıyla ve bakımıyla ilgilenen aile üyesi/üyeleri (anne/ baba/kardeş/akraba/bakıcı) ve SP rehabilitasyonunda çalışan 50 (22 kadın, 28 erkek) fizyoterapistin katılımıyla gerçekleştirildi. SP'lilerin yaş, cinsiyet, vücut kitle indeksi (VKİ), ailelerinin gelir düzeyi gibi sosyodemografik özellikleri ile SP’nin klinik tipi, vücut etkilenimi, fonksiyonel seviye ve AC cihaz kullanımı sorgulandı. Değerlendirme esnasında aktif epileptik nöbet geçiren, yanında herhangi bir ebeveyni bulunmayan çocuklar ile SP rehabilitasyonunda beş yıldan daha az mesleki tecrübeye sahip fizyoterapistler çalışmaya alınmadı.

SP'li çocukların fonksiyonel seviyesi Türkçe geçerlilik ve güvenirliği yapılmış Kaba Motor Fonksiyon Sınıflandırma Sistemi (KMFSS) ile değerlendirildi. ${ }^{17}$ SP'li çocuklar için geliştirilmiş olan KMFSS oturma, yer değiştirme ve hareketliliğe vurgu yaparak çocuğun kendi başlattığı hareketlere dayanan bir sınıflandırma sistemidir. Çocukların motor fonksiyonları yaşa bağlı olarak değiştiğinden, her seviye için 2 yaşın altı, 2-4 yaş, 4-6 yaş, 6-12 yaş ve 12-18 yaşları olmak üzere her yaş grubundaki çocuğa göre fonksiyonlar tanımlanmıștır. ${ }^{18}$ 
AC kullanım ihtiyacı ve hangi cihazların kullanılması gerektiği SP'li çocuğu rehabilitasyona alan fizyoterapiste sorularak karar verildi. AC kullanımını etkileyen faktörleri belirlemek için SP'li çocukların ailelerine ve fizyoterapistlere araştırmacı tarafından hazırlanan anket uygulandı. Anket içeriği AC’lerin SP rehabilitasyonuna katkısı, çocukların öz bakım işlemlerine kolaylaştırıcı etkisi, kolay uygulanabilirlik ve taşınabilirliği ile kullanımdan duyulan memnuniyeti ve mimari engellerin kullanıma etkisini beşli likert tipi ölçek (çok düşük, düşük, orta, yüksek, çok yüksek) ile sorgulayan beş sorudan oluşmaktaydı. Her bir soru 1 ile 5 arasinda puanlanmakta olup toplamda en fazla 25 puan alınabilmektedir. Anket sonucunda alınan yüksek puanlar olumlu etkiye, düşük puanlar ise olumsuz etkiye sahip olduğunu göstermektedir.

Çalışma Haliç Üniversitesi Girişimsel Olmayan Klinik Araştırmalar Etik Kurulu tarafından onaylandı (26.09.2014, 5/7). Katılımcılar çalışma hakkında bilgilendirildi ve yazılı aydınlatılmış onam formu katılımcılara okunarak imza alındı.

\section{İstatiksel Analiz}

Verilerin istatiksel analizi için SSPS 22.0 (Statistical Package for Social Sciences, ABD) analiz programı kullanıldı. Örneklemin demografik ve klinik özellikleri için tanımlayıcı istatistik kullanıldı. Katılımcıların ölçümle belirtilen puanları ortalama, standart sapma, minimum ve maksimum değerleri ile ifade edilirken, sayımla belirtilen SP'lilerin klinik tipleri ve kullandıkları AC’ler sayı ve yüzdelik (\%) değerleri ile tablolarda verildi. KMFSS seviyeleri ile AC kullanım gerekliliği ki-kare testi karşılaştırıldı. İstatistiksel anlamlılık düzeyi $\mathrm{p}<0.05$ olarak kabul edildi.

\section{BULGULAR}

Olguların demografik özellikleri ile SP’li çocukların klinik tipi ve fonksiyonel seviyeleri Tablo 1'de gösterildi. Çalışmaya katılan 93 SP'li çocuğun 46’sı $(\% 49,5)$ kız ve 47 'si $(\% 50,50)$ erkek, yaş ortalamaları $6,74 \pm 4.32$ yıl, VKİ $19,04 \pm 6,18 \mathrm{~kg} / \mathrm{m}^{2}$ idi. Klinik sinıflamada SP'lilerin \%86's1 spastik, \%14'ü diskenik-ataksik tip, vücut tutulumunda ise \%36,60’1 kuadriplejik, \%32,30’u diplejik, \%25,70'i hemiplejik, \%5,40’1 monoplejik etkilenim göstermekteydi. KMFSS seviyeleri \%28'inin seviye I, \%17,20'si seviye II, $\% 16,10$ seviye III, \%19,40'1 seviye IV, \%19,40'1 seviye V idi. SP'li çocukların \%87,10'una anneleri, \%7,50'sine babaları, \%5,40'ına ise diğer aile üyeleri tarafından bakım sağlanmaktaydı. Ailelerin aylık toplam geliri \%25,80'inin asgari ücret, \%48,50'sinin asgari ücretin bir-iki katı aralığı, \%16’sının asgari ücretin iki-üç kat aralığı, \%9,70'inin asgari ücretin üç-dört kat aralığı idi.

Olguların AC kullanımına ilişkin bulgular Tablo 2'de gösterildi. SP'li çocukların AC kullanım gerekliliği \%67,70 gerçekte kullanım oranı ise \%30,10 idi. AC kullanan SP'li çocukların \%85,70'ine bu cihazların fizyoterapistler tarafından önerildiği bulundu. AC kullananların ailelerinden \%75'inin cihazlara erişimde başta ekonomik (\%81) olmak üzere çeşitli zorluklar yaşadığı bulundu. SP’li çocukların kullandığı 35 AC’nin \%25,80'i ayakta konumlandırma cihazı, \%20'si tekerlekli sandalye, \%20'si oturma gereci, $\% 17,10$ 'u walker, $\% 17,10$ 'u pozisyonlama gereci idi.

Fizyoterapistlerin ve SP'li çocuğa sahip ailelerin AC kullanımından duydukları memnuniyet ile bu cihazların öz bakım işlemlerine kolaylaştırıcı etkisini, taşınabilirlik/ hafiflik özellikleri ve mimari yapıların kullanılmalarına engel düzeyi Tablo 3'te gösterildi. SP'li çocukların rehabilitasyonunda AC kullanılmasından duyulan memnuniyeti fizyoterapistlerin \%52'si yüksek, \%40'ı çok yüksek, ailelerin ise \%50'si yüksek, \%35,70'i çok yüksek olarak belirtti. AC kullanmanın SP rehabilitasyonuna etkisini fizyoterapistlerin \%56'sı yüksek, \%24'i orta, ailelerin ise \%39,30'u orta, \%28,60'ı yüksek olarak belirtti. AC’lerin SP'li çocukların öz bakım işlerine sağladığı kolaylığı fizyoterapistlerin \%40'ı yüksek, \%36’sı orta, ailelerin ise \%35,70'i yüksek, \%28,60'1 orta olarak belirtti. AC kullanımına mimari yapıların engelliliği fizyoterapistlerin \%50'si orta, \%32'si yüksek, ailelerin ise \%42,90'1 orta, \%28,60'1 yüksek olarak belirtti. AC’lerin kolay uygulanabilirlik, hafiflik ve taşına- 
Sakarya Tip Dergisi 2020;10(4):592-599

KURTARAN., Serebral Palsili Çocuklarda Adaptif Cihaz Kullanımını

\begin{tabular}{|c|c|c|c|}
\hline & Özellik & \multicolumn{2}{|c|}{ Ort. \pm SS } \\
\hline \multirow{3}{*}{ Yaş (yıl) } & SP'li çocuk & \multicolumn{2}{|c|}{$6,74 \pm 4,32$} \\
\hline & Aile üyesi & \multicolumn{2}{|c|}{$38,46 \pm 7,21$} \\
\hline & Fizyoterapist & \multicolumn{2}{|c|}{$30,15 \pm 3,40$} \\
\hline \multirow{3}{*}{ VKİ $\left(\mathbf{k g} / \mathbf{m}^{2}\right)$} & SP'li çocuk & \multicolumn{2}{|c|}{$19,04 \pm 6,18$} \\
\hline & Aile üyesi & \multicolumn{2}{|c|}{$27,52 \pm 5,74$} \\
\hline & Fizyoterapist & \multicolumn{2}{|c|}{$25,18 \pm 4,85$} \\
\hline & Özellik & (n) & $\%$ \\
\hline \multirow{3}{*}{ Cinsiyet (K/E) } & SP’li çocuk & $46 / 47$ & $49,50 / 50,50$ \\
\hline & Aile üyesi & $86 / 7$ & $92,50 / 7,550$ \\
\hline & Fizyoterapist & $30 / 20$ & $60 / 40$ \\
\hline \multirow{4}{*}{ SP'nin klinik tipi } & Spastik & 76 & 81,60 \\
\hline & Ataksik & 8 & 8,60 \\
\hline & Diskinetik & 5 & 5,40 \\
\hline & Karışık & 4 & 4,40 \\
\hline \multirow{5}{*}{ KMFSS seviyesi (\%(n)) } & I & 26 & 28 \\
\hline & II & 16 & 17,20 \\
\hline & III & 15 & 16,10 \\
\hline & IV & 16 & 17,20 \\
\hline & $\mathrm{V}$ & 20 & 21,50 \\
\hline \multirow{3}{*}{$\begin{array}{l}\text { SP'li çocukların bakımını } \\
\text { sağlayan üyesi }\end{array}$} & Anne & 81 & 87,10 \\
\hline & Baba & 7 & 7,50 \\
\hline & Diğer aile üyesi & 5 & 5,40 \\
\hline \multirow{4}{*}{$\begin{array}{l}\text { Ailelerin toplam aylık gelir } \\
\text { düzeyi }\end{array}$} & Asgari ücret & 24 & 25,80 \\
\hline & Asgari ücretin bir-iki katı aralığı & 45 & 48,40 \\
\hline & Asgari ücretin iki-üç katı aralığı & 15 & 16,10 \\
\hline & Asgari ücretin üç-dört katı aralığı & 9 & 9,70 \\
\hline
\end{tabular}

SP: Serebral palsi, Ort.: Ortalama, SS: Standart sapma, VKİ: Vücut kitle indeksi, K: Kadın, E: Erkek, KMFSS: Kaba motor fonksiyon sınıflandirma sistemi

bilirlik seviyesini fizyoterapistlerin \%48'i orta, \%32'si düşük, ailelerin ise \%53,60’1 orta, \%25’i düşük olarak belirtti. SP'li çocukların AC kullanımı ile fonksiyonel seviyelerinin karşılaştırılması Tablo 4’te gösterildi. KMFSS seviyeleri ile AC kullanımı gerekliliği karşılaştırıldığında istatiksel olarak anlamlı sonuç bulundu $(\mathrm{p}=0,001)$. SP’li çocuklardan AC kullanması gerekenlerin sayısı fonksiyonel seviyelerine göre KMFSS V için 20, IV için 16, III için 15 idi. SP'li çocukların KMFSS seviyeleri ile mevcut AC kullanma durumu karşılaştırıldığında istatiksel olarak anlamlı sonuç bulundu $(\mathrm{p}=0,003)$. 
Sakarya Tip Dergisi 2020;10(4):592-599

KURTARAN., Serebral Palsili Çocuklarda Adaptif Cihaz Kullanımını

\begin{tabular}{|c|c|c|c|}
\hline \multicolumn{2}{|l|}{ Değişken } & \multirow{2}{*}{$\begin{array}{l}\mathbf{n} \\
63\end{array}$} & \multirow{2}{*}{$\begin{array}{c}\% \\
67,70\end{array}$} \\
\hline \multirow{2}{*}{ SP'lilerden AC kullanma gerekliliği (n:93) } & Evet & & \\
\hline & Hayır & 30 & 32,30 \\
\hline \multirow{2}{*}{ Mevcut durumda AC'ye sahip olma (n:93) } & Evet & 28 & 30,10 \\
\hline & Hayır & 65 & 69,90 \\
\hline \multirow{5}{*}{ Kullanılan AC'ların tipleri (n:35) } & Walker & 6 & 17,10 \\
\hline & Pozisyonlama Gereci & 6 & 17,10 \\
\hline & Oturma Gereci & 7 & 20 \\
\hline & Ayakta Durma Sehpas1 & 9 & 25,80 \\
\hline & Tekerlekli Sandalye & 7 & 20 \\
\hline \multirow{3}{*}{ AC kullanması gerekenlerin önerilen cihazlara sahipliği (n:63) } & Tamamına Sahip & 4 & 6,30 \\
\hline & Kismen Sahip & 24 & 38,10 \\
\hline & Sahip Değil & 35 & 55,60 \\
\hline \multirow{2}{*}{ AC temininde zorlukla karşılaşma (n:28) } & Evet & 21 & 75 \\
\hline & Hayır & 7 & 25 \\
\hline \multirow{3}{*}{ AC temininde karşıllaşılan zorluklar (n:28) } & Ekonomik & 17 & 81 \\
\hline & Sigorta İşlemleri & 3 & 14,20 \\
\hline & Öneri/Bilgi & 1 & 4,80 \\
\hline \multirow{2}{*}{ AC kullanmayı öneren (n:28) } & Fizyoterapist & 24 & 85,70 \\
\hline & Hekim & 4 & 14,30 \\
\hline
\end{tabular}

Tablo 3. Fizyoterapistlerin ve Ailelerin SP Rehabilitasyonunda AC Kullanımına İlişkin Değerlendirme Sonuçları

\begin{tabular}{|c|c|c|c|c|c|c|}
\hline & & \multicolumn{5}{|c|}{ Fizyoterapist/Aile (\%) } \\
\hline & & Çok Düşük & Düşük & Orta & Yüksek & Çok Yüksek \\
\hline \multicolumn{2}{|c|}{ AC kullanımından duyulan memnuniyet } & $0 / 0$ & $0 / 0$ & $8 / 14,30$ & $52 / 50$ & $40 / 35,70$ \\
\hline \multicolumn{2}{|c|}{ AC kullanımının SP rehabilitasyona etkisi } & $0 / 10,70$ & $4 / 7,10$ & $24 / 39,30$ & $56 / 28,60$ & $16 / 14,30$ \\
\hline \multicolumn{2}{|c|}{ AC’lerin öz bakım işlerinde kolaylaştırıcı etkisi } & $0 / 14,30$ & $6 / 7,10$ & $36 / 28,60$ & $40 / 35,70$ & $18 / 14,30$ \\
\hline \multicolumn{2}{|c|}{ Mimari yapıların AC kullanımına olumsuz etkisi } & $2 / 7,10$ & $6 / 10,70$ & $50 / 42,90$ & $32 / 28,60$ & $10 / 10,70$ \\
\hline \multicolumn{2}{|c|}{$\begin{array}{l}\text { AC'lerin kolay uygulanabilirlik, hafiflik ve taşınabilir- } \\
\text { lik seviyesi }\end{array}$} & $4 / 14,30$ & $32 / 25$ & $48 / 53,60$ & $16 / 7,10$ & $0 / 0$ \\
\hline \multirow{2}{*}{ Toplam sonuç (Ort. \pm SS) } & Fizyoterapist & \multicolumn{5}{|c|}{$18,10 \pm 4,16$} \\
\hline & Aile & \multicolumn{5}{|c|}{$16,57 \pm 3,09$} \\
\hline
\end{tabular}

\begin{tabular}{|c|c|c|c|c|c|c|c|}
\hline \multirow{2}{*}{\multicolumn{2}{|c|}{ Değişken }} & \multicolumn{2}{|c|}{ AC kullanma gerekliliği } & \multirow{2}{*}{$\mathbf{p}$} & \multicolumn{2}{|c|}{ Şu anda AC kullanımı } & \multirow{2}{*}{$\mathbf{p}$} \\
\hline & & Evet & Hayır & & Evet & Hayır & \\
\hline \multirow{5}{*}{$\begin{array}{l}\text { KMFSS } \\
\text { seviyesi }\end{array}$} & I & 0 & 26 & \multirow{6}{*}{$0,001^{\star}$} & 0 & 26 & \multirow{6}{*}{$0,003^{\star}$} \\
\hline & II & 12 & 4 & & 1 & 15 & \\
\hline & III & 15 & 0 & & 9 & 6 & \\
\hline & IV & 16 & 0 & & 10 & 6 & \\
\hline & V & 20 & 0 & & 8 & 12 & \\
\hline \multicolumn{2}{|l|}{$\mathrm{n}$} & 63 & 30 & & 28 & 65 & \\
\hline
\end{tabular}




\section{TARTIŞMA}

SP'li çocukların AC kullanımı hakkında bilgi edinmek, cihazların temin edilmesinde ve kullanımında karşılaşılan zorlukları tespit etmek, SP'li çocuğa sahip ebeveynlerin ve SP rehabilitasyonunda çalışan fizyoterapistlerin AC kullanımından duydukları memnuniyeti ölçmek amacıyla yaptı̆̆ımız çalışmada sonuçlarımız AC kullanımının öngörülenden düşük olduğu buna rağmen fizyoterapistlerin ve ebeveynlerin SP'li çocukların rehabilitasyonunda bu cihazların kullanılmasından memnun oldukları görüldü.

Çalışmamızda SP'lilerin en yaygın klinik tipi $\% 81,70$ oranında spastik tip idi, bu sonuç literatür ile uyumludur. ${ }^{19,20}$ Ülkemizde yapılan farklı çalışmalarda Sucuoğlu \%81,80, Öneş ve ark. \%80 oranında spastik tip SP saptamışlar. ${ }^{19,20}$ Spastik tip SP'liler AC'lerden yarar sağlama ve kullanım kolaylığı açısından SP tipleri arasında en avantajlı grup olduğu bilinmektedir. Çalışmamızda da AC kullanan 28 SP'li çocuktan 23'ü spastik tip, 2'si ataksik tip, 2'si diskinetik, l'i karışık tip idi. Ayrıca spastik SP'lilerin kullandığ 1 AC’ler mobiliteye ve postural destek sağlamaya yönelik cihazlar iken diğer tiptekilerin sadece postüral destek sağlamak amacıyla kullanılan cihazlara sahip olduğu görüldü. Çalışmamızdaki SP'li çocukların fonksiyonel seviyeleri KMFSS'ye göre \%17,20'si seviye II, \%16,10'u seviye III, \%19,40’1 seviye IV, \%19,40’1 seviye V idi. Bu durum SP'lilerin çoğunda bağımsızlığının azalarak fonksiyonel seviyelerinin kötüleştiği ve mobilizasyon ve postüral destek için çeşitli yardımcı desteklere ihtiyacı olduğunu göstermektedir. Çalışmamızda spastik tip SP'li oranının fazlalı$\breve{g}_{1}$ fonksiyonel seviyesi kötü olanların sayılarının da fazla olmasıyla birlikte düşünüldüğünde; çalışmamızdaki SP’li çocukların yarısından fazlasının ev içinde veya toplum içinde mobilizasyonda zorluk yaşadığı ve fonksiyonel olabilmeleri için AC’leri kullanma gereksinimine ihtiyaçları olduğunu ifade etmektedir.

SP'li çocukların fizyoterapistlerinin önerileri doğrultusunda öngörülen AC kullanım gerekliliği \%67,70 iken gerçekte tespit edilen kullanım oranı \%30,10 idi. Buna göre çalışmamızda AC kullanması gereken SP’li çocuklardan \%69,90'ı herhangi bir AC’ye sahip değildi. AC kullanması gereken SP'li çocukların \%6,30'u fonksiyonel seviyelerine göre kullanması gereken AC'lerin tamamına sahip, $\% 31,10$ 'u kısmen sahip, \%55,60' 1 ise herhangi bir AC'ye sahip değil idi. Bu durum SP'li çocuklarda AC kullanımının yeterli düzeyde olmadığını ifade etmekte olup olgularımızın yarısından fazlasının rehabilitasyon açısından AC’leri kullanmaları gerektiği halde fonksiyonel seviyelerine göre öngörülen AC’lere sahip olmadıklarını göstermektedir. Çalışmamızda AC kullanan çocukların \%85,70'ine bu cihazların fizyoterapistler tarafından önerildiği bulundu. $\mathrm{Bu}$ durum fizyoterapistlerin rehabilitasyon merkezlerinde SP'li çocukların rehabilitasyonunda birinci derecede ve uzun süre yer almaları nedeniyle çocukların fonksiyonel seviyelerini daha iyi analiz ederek ihtiyaçları olan destekleyici cihazları önermeleri ile açıklanabilir.

Literatürde SP'li çocukların AC'leri kullanımını etkileyen faktörleri, ailelerin ve bu alanda çalışan fizyoterapistlerin bu cihazların kullanılmasından duydukları memnuniyeti sorgulayan çalışmalara rastlamadık. Bu yönüyle çalışmamızın sonuçları bir ilk olma özelliği taşımakta ve literatürde önemli bir boşluğu dolduracağı düşünülmektedir. Buna karşın literatürde SP'li çocuklarda bazı AC'lerin kullanımını ve etkisini değerlendiren çalışmalar bulunmaktadır. $\mathrm{Bu}$ nedenle çalışmamızın sonuçlarını bu çalışmalarla karşılaştırdık.

Curcy ve ark, Brezilya'da 113 SP'li çocuğun farklı ortamlarda (evde, okulda ve toplum içinde) mobilizasyon yöntemleri ile ailelerin sosyoekonomik seviyeleri arasındaki ilişkiyi incelemişler. SP'lilerin mobilizasyona yardımcı olarak fonksiyonel düzeyi KMFSS'ye göre seviye II olanlar hiçbir cihaz kullanmadıklarını, seviye III’te yürüteç veya tekerlekli sandalye, seviye IV'de tekerlekli sandalye kullanıldığını tespit etmişler. Sosyoekonomik düzeyin ev içinde mobilizasyonu etkilediğini, ailesinin sosyoekonomik seviyesi düşük olanların ev içi hareketliliği emekleme, sürünme gibi bireysel çabalar veya ailelerin fiziksel desteği ile sosyoekonomik seviyesi yüksek olanlar ise TS ile gerçek- 
leştirdiklerini tespit etmişler. ${ }^{21}$ Çalışmamızda fonksiyonel düzeyi KMFSS seviye III, IV olanlar arasında bir kısmının TS kullanmasına karşın SP’lilerin ailelerin büyük bir kısmının düşük gelir düzeyine sahip olması ve AC’lerin temin edilmesinde ailelerinin büyük kısmının ekonomik zorluk yaşaması; AC kullanımı nın yetersiz olması ile ailelerin düşük gelir düzeyi arasında ilişkili olabileceğini düşündürmektedir.

Rigby ve ark, SP’li çocuklarda uyarlanabilir oturma cihazları kullanmanın aileleri için öz bakım ve oyun aktivitelerini daha mümkün hale getirdiğini tespit etmişlerdir. ${ }^{22}$ Çalışmamızda ailelerin \%78,60'ı, fizyoterapistlerin \%94'ü AC’leri kullanmanın SP’li çocukların öz bakım işlemlerinde kolaylaştırıcı etkisinin orta ve üstünde olduğunu belirtti. AC’lerin kolay uygulanabilirlik, hafiflik ve taşınabilirlik düzeyini fizyoterapistlerin \%64'ü, ailelerin ise \%60,70'i orta ve yüksek olarak belirtti. Aileler ile fizyoterapistler arasında görülen bu algı farkı, her iki grup da AC’leri öz bakımı kolaylaştırıcı görmesine rağmen, ailelerin AC’leri kurma ve çocuğa uyarlamanın gerektirdiği iş yükünü daha fazla göz önünde tutmalarından kaynaklanıyor olabilir. Robdy ve ark. İsveç'te 3-18 yaş arasındaki 562 SP'li çocuğun oturma ve ayakta durma performansını değerlendirmişler. SP'li çocukların \%42'sinin adaptif oturma cihazlarını, \%31'nin ayakta durmayı sağlayan AC'leri kullandığını ve bu cihazların en sık kullanım yaşının 3-6 yaş aralığg olduğunu tespit etmişlerdir. Oturma ve ayakta durmak için AC kullanımının KMFSS seviyeleriyle aynı yönlü doğrusal arttığını tespit etmişlerdir $(\mathrm{p}=0,001) .{ }^{23}$ Çalışmamızda AC kullanımı ile KMFSS seviyeleri arasında aynı yönlü doğrusal ilişki bulunmakta olup, fonksiyonel seviye azaldıkça AC kullanımı artmakta idi ( $\mathrm{p}=0,003)$. Ayrıca olgularımızdan \%7,50'si adaptif oturma cihazlarını, \%9,70'i ayakta dik konumlandırma cihazlarını kullanmakta idi. SP'li çocukların ihtiyaç duyduğu AC’ler İsveç’te Yardımcı Teknoloji Merkezleri tarafından ücretsiz karşılanırken, ülkemizde ise AC’lerin bir kısmının standart ve özellikli tipleri için SGK tarafından karşılanmakta ve ailelere geri ödemeler yapılmaktır. Ancak SGK tarafindan yapılan bu ödemeler
AC’lerin piyasa fiyatlarının çok altında olmasından dolayı geri ödemeler ile piyasa ücretleri arasında ailelerin çoğunluğunun karşılamakta zorlandıkları fiyat farkları oluşmaktadir. $^{24}$

Çalışmamızın sonucunda SP'li çocuklarda fonksiyonel seviyenin azalmasına bağlı olarak AC kullanımının arttığ 1 buna karşın AC kullanımının öngörülenin çok altında yer aldığı, ailelerin cihazlara erişimde ekonomik zorluk yaşadığı bulundu. Hem ailelerin hem de fizyoterapistlerin büyük çoğunluğu SP rehabilitasyonunda AC kullanmanın önemli bir yere sahip olduğunu ve bu durumdan memnun olduklarını belirtti. SP'li çocukların rehabilitasyonunda, bağımsızlık seviyelerinin geliştirilmesinde ayrıca mental ve motor gelişimlerinde önemli katkısı olan AC kullanımının arttırılmasında tüm cihazların SGK ödemeleri kapsamina alınması ve geri ödemeler ile piyasa fiyatları arasında oluşan ücret farkının ortadan kaldırılması önemli bir yere sahip olacaktır. Ebeveynlerin çocukların ihtiyacı olan doğru AC’lere erişimi kolaylaştırılmalı, bu amaçla Sağlık Bakanlığı ve sigorta kurumları düzeyinde gerekli çalışmalar yapılmalıdır.

Gelecekte daha geniş sayıdaki SP popülasyonunda AC kullanmama nedenlerini de göz önünde bulundurarak, farklı AC tipleri ile fonksiyonel seviye arasındaki ilişkiyi inceleyen çalışmaların bu konu hakkında daha değerli bilgiler sağlayacağı görüşündeyiz.

\section{Etik Kurul Onayı}

Çalışma Haliç Üniversitesi Girişimsel Olmayan Klinik Araştırmalar Etik Kurulu tarafından onaylandı (26.09.2014, 5/7). 
Sakarya Tip Dergisi 2020;10(4):592-599

KURTARAN., Serebral Palsili Çocuklarda Adaptif Cihaz Kullanımını

\section{Kaynaklar}

1. Oskoui M, Coutinho F, Dykeman J, Jetté N, Pringsheim T. An update on the prevalence of CP: a systematic review and meta-analysis. Dev Med Child Neurol 2013;55(6):509-519.

2. Krigger KW. CP: an overview. Am Fam Phys 2006;73(1):91-100.

3. Christensen D, Braun KVN, Doernberg NA, et al. Prevalence of cerebral palsy, co-occurring autism spectrum disorders, and motor functioning-autism and developmental disabilities monitoring network, USA, 2008. Dev Med Child Neurol 2014;56:59-65.

4. Martin L, Baker R, Harvey A. A systematic review of common physiotherapy interventions in school-aged children with cerebral palsy. Phys Occup Ther Pediatr 2010;30(4):294-312.

5. Clutterbuck G, Auld M, Johnston L. Active exercise interventions improve gross motor function of ambulant/semi-ambulant children with cerebral palsy: a systematic review. Disabil Rehabil 2019;41(10):1131-1151.

6. Sorsdahl A.B, Nilssen R.M, Strand L.I. Observer reliability of the gross motor performance measure and quality of upper 66 extremity skills test, based on video recordings. Developmental Medicine and Child Neurology 2008;50:146-151.

7. Beckung E, Hagberg G, Uldall P, Cans C. Surveillance of CP in Europe probability of walking in children with CP in Europe. Pediatrics 2008;121(1):e187-e192.

8. Tarsuslu T, Livanelioğlu A. Serebral paralizili bireylerde motor limitasyonun mobilite ve bağımsızlık düzeyi üzerine etkisi. Fizyoterapi Rehabilitasyon 2008;19(3):117-122.

9. Yalçın S, Özaras N, Dormans J. Serebral palsi tedavi ve rehabilitasyon. İstanbul: Mas Matbaactlik; 2000.

10. Özcan O, Arpacıŏ̆lu O, Turan B. Nörorehabilitasyon. 2. Baskı. Bursa: Güneș \& Nobel Tip Kitabevleri; 2000. s:137-48.

11. Bax M, Goldstein M, Rosenbaum P, Paneth N. Proposed definition and classification of cerebral palsy. Dev Med Child Neurol 2005;47(8):571-6.

12. Rosenbaum P, Stewart D. The WHO international classification of functioning, disability and health: A model to guide clinical thinking, practice and research in the field of cerebral palsy. Seminars in Paediatr Neurol 2004;2(1):5-10.

13. Pakula AT, Braun KVN, Yeargin-Allsopp M. Cerebral palsy: classification and epidemiology. Phys Med Rehabil Clin N Am 2009;20(3):425-52.
14. Yavuz B, Çimen S. Serebral palsili çocukların öz bakım becerilerini gerçekleștirme düzeyleri ve etkileyen etmenlerin incelenmesi. Cumhuriyet Üniversitesi Hemșirelik Yüksekokulu Dergisi 2007;11(1):17-26.

15. Novak I, McIntyre S, Morgan C, et al. A systematic review of interventions for children with cerebral palsy: state of the evidence. Dev Med Child Neurol 2013;55: 885-910.

16. Ryan SE. Lessons learned from studying the functional impact of adaptive seating interventions for children with cerebral palsy. Dev Med Child Neurol 2016;58(4):78-82.

17. https://canchild.ca/system/tenon/assets/attachments/000/000/083/original/GMFCS-ER_ Translation-Turksih.pdf

18. Palisano R, Rosenbaum P, Bartlett D, Livingston M. Content validity of the expanded and revised Gross Motor Function Classification System. Developmental Medicine \& Child Neurology 2008;50(10):744-750.

19. Sucuoğlu H. Serebral palsili hastaların demografik ve klinik özellikleri. İstanbul Med J 2018;19(3):219-24.

20. Ones K, Yilmaz E, Cetinkaya B, Caglar N. Assessment of the quality of life of mothers of children with cerebral palsy (primary caregivers). Neurorehabil Neural Repair 2005;19:2327.

21. Cury VCR, Figueiredo PRP, Mancini MC. Environmental settings and families socioeconomic status influence mobility and the use of mobility devices by children with cerebral palsy. Arq. Neuropsiquiatr 2012;71(2):100-105.

22. Rigby PJ, Ryan SE, Campbell KA. Effect of adaptive seating devices on the activity performance of children with cerebral palsy. Arch Phys Med Rehabil 2009;90:1389-95.

23. Rodby E, Bousquet E, Hägglund G. Sitting and standing performance in a total population of children with cerebral palsy: a cross-sectional study. BMC Musculoskeletal Disorders 2010;11:131.

24. http://www.sgk.gov.tr, Erişsim tarihi: 17.01.2019. 